\title{
Foghs nye job: general eller sekretær?
}

\section{Kristian Søby Kristensen}

\section{Anders Fogh Rasmussen får nok at se til i sit nye job. Han skal udfylde rollen som talsmand; som koncerndirektør for de mange civile ansatte; som mødeleder når hans 28 chefer skal blive enige, og som ekstern chefforhandler med en ofte skrøbelig konsensus i ryggen}

Den 1. august 2009 begyndte Anders Fogh Rasmussen i sit nye job som generalsekretær for NATO. Det er den højeste internationale post, en dansker har besat. Men hvad går jobbet ud på? Hvad vil Fogh i sit nye job, og hvilke opgaver og politiske emner kommer han til at fokusere på? Og hvor meget kan han egentlig påvirke NATO? Er han general mere end sekretær eller omvendt?

Anders Fogh Rasmussen er ikke i tvivl. På DR1's udenrigspolitiske magasin Horisont den 22. juni 2009 svarede han - ikke overraskende - at jobbeskrivelsen som general var mere passende end sekretær. Al-Qaeda synes også at tillægge jobbet en del betydning. I en udtalelse kommenterer organisationen udnævnelsen af Fogh til generalsekretær, og karakteriserer ham som en af 'Vestens tyranner' på højde med amerikanske, britiske og israelske statsledere. Tyran bliver Fogh ikke i NATO. Selv generaler har politiske chefer, de er underlagt. NATO har 28 medlemslande; derfor har Anders Fogh 28 chefer. Det er i sig selv en udfordring. Og jobbets egentlige - og vigtigste - funktion er at sørge for, at de 28 chefer kan blive enige. Alle beslutninger i NATO tages i enighed. Derfor er det begrænset, hvor meget Anders Fogh Rasmussen som god general kan lede fra fronten. Alle medlemslande skal tages i ed, alle skal med på vognen, før NATO kan bevæge sig.

Det betyder ikke, at jobbet som 
generalsekretær ikke er vigtigt. Tværtom er posten essentiel for NATO. Uden en dygtig generalsekretær, der kan tage ansvar for emner og dagsordner, fungere uafhængigt af nationale interesser og lede de politiske diskussioner, er der intet velfungerende NATO. En dygtig generalsekretær kan rykke konsensus og dermed også rykke NATO.

\section{En jobbeskrivelse}

Det er derfor relevant at se på, hvad stillingen indeholder. Hvilke redskaber og muligheder har man som generalsekretær? En generalsekretærs muligheder hænger naturligvis tæt sammen med den politiske situation og dagsorden i NATO. Derfor skal jobbeskrivelsen ses i sammenhæng med NATOs udfordringer. Kort sagt: Hvilke prioriteringer og emner kan vi forvente vil indgå i Anders Foghs plan?

Formelt udfylder generalsekretæren fire roller. For det første er han formand for det Nordatlantiske Råd, når det holder møder. Rådet kan mødes på forskelligt niveau. I hverdagen - hver onsdag - mødes medlemslandenes NATO-ambassadører. Men når større beslutninger træffes, udgøres Rådet af forsvars- eller udenrigsministrene, og under såkaldte NATO-topmøder, som i april 2009 i Strasbourg/Kehl, af regeringscheferne. I alle tilfælde leder generalsekretæren møderne.

For det andet er generalsekretæ- ren den øverste leder af NATOs civile embedsværk - den såkaldte internationale stab - der, sammen med generalsekretæren, forbereder $m \varnothing$ der og beslutninger og sørger for, at Rådets vilje føres ud i livet. I det hele taget sørger den internationale stab for, at organisationen fungerer i dagligdagen.

For det tredje er generalsekretæren alliancens vigtigste ansigt udadtil. Det er hans (måske engang hendes) ansvar at kommunikere beslutninger og budskaber fra NATO til den brede offentlighed i medlemslandene. Efterhånden som NATO har påtaget sig flere og flere roller uden for sit traditionelle euro-atlantiske område, er kommunikationsdelen af jobbet blevet endnu mere vigtig. Generalsekretæren skal også udtrykke NATOs holdning og beslutninger til mange lande uden for medlemskredsen og til det internationale samfund i almindelighed.

For det fjerde, og netop i forhold til andre lande og organisationer, er generalsekretærens job blevet forøget i forhold til tidligere. Eftersom opgaver og operationer sammen med - og i - andre lande fylder mere og mere for Alliancen, forhandler NATO ofte på centrale felter med andre aktører. Her er generalsekretæren også NATOs repræsentant. Med et mandat fra det Nordatlantiske Råd forhandler han NATOs politiske forhold til og aftaler med en lang række af andre aktører - fra Rusland til Japan og Afghanistan og 
fra FN til EU og den Afrikanske Union. Der er altså nok at tage fat på som generalsekretær. Man skal udfylde rollen som talsmand, som koncerndirektør for de mange civile ansatte, som mødeleder når ens 28 chefer skal blive enige, og som ekstern chefforhandler med en ofte skrøbelig konsensus i ryggen.

Men selv om der er meget at lave, er der ikke megen formel politisk magt forbundet med disse opgaver. Den grundlæggende politikformulering i NATO foregår i altovervejende grad i Rådet, og på foranledning af medlemslandene. Generalsekretæren er bundet af Rådet og de beslutninger, der tages der. Generalsekretæren kan ikke gøre noget uden mandat fra Rådet.

\section{Generalsekretærens beføjelser}

Der er dermed i udgangspunktet ikke meget politisk pondus i jobbet - man bestemmer som generalsekretær formelt set ikke meget i NATOs politiske beslutningsproces.

Stillingen er på sin vis tom, og hvis den skal være magtfuld, er det i høj grad op til personen at udfylde den. Men en person, der netop både er en dygtig administrator og politiker, kan nogle gange skabe sine egne muligheder for også at være general. En dygtig generalsekretær er med andre ord en magtfuld generalsekretær. Historisk set har generalsekretærer som for eksempel Lord Ismay og Manfred Wörner spil- let centrale roller $i$ at redefinere NATO i en bestemt retning dels i forhold til det lange stræk i den Kolde Krig og dels til den radikalt nye sikkerhedspolitiske situation efter afslutningen af den Kolde Krig.

I mange af de arbejdsopgaver generalsekretæren varetager, findes der muligheder for at påvirke NATOs retning. Generalsekretæren er - selv uden megen formel magt omdrejningspunktet for en stor del af det daglige politiske arbejde i NATO. Det kan gøre ham til en central person. En dygtig og dermed magtfuld generalsekretær formår at kombinere sine personlige kvalifikationer og egenskaber med de institutionelle ressourcer og roller, som posten indeholder.

Generalsekretæren er chef for NATOs bureaukrati. Det arbejde, der varetages af NATOs bureaukrati, handler i høj grad om at producere viden. Strategipapirer, beslutningsforslag - samt deres rationaler og begrundelser, afrapporteringer fra NATOs utallige komiteer og afholdelse af konferencer og seminarer. Tilsammen er de alle medvirkende til at skabe den basis af viden, ud fra hvilken NATO handler, og det Nordatlantiske Råd tager sine beslutninger. Viden er kort sagt magt, og generalsekretæren har indflydelse på, hvordan viden produceres i NATO.

Det samme gør sig gældende i forhold til selve beslutningsprocessen i Rådet. Det er generalsekretærens opgave at sørge for enighed - at le- 
de møderne på en måde, så der kan opnås resultater og træffes beslutninger. Forud for afholdelse af selve møderne - specielt topmøder og andre vigtige møder - ligger en omfattende forberedelse. Der foregår hele tiden konsultationer og forhandlinger i korridorerne medlemslandene imellem, og mellem medlemslandene og generalsekretæren, hvori strategier for at opnå konsensus på møderne udarbejdes. Som ham, der skal samle trådene, bliver generalsekretæren en central og dermed potentielt indflydelsesrig person i dette korridorspil.

Rollen som øverste talsmand for Alliancen giver generalsekretæren en anseelig dagsordensættende magt. Den er en vigtig sikkerhedspolitisk kommunikationsplatform. Generalsekretæren kan ikke bevæge sig ud over den konsensus, som Rådet udtrykker. Ofte skal generalsekretæren påpasseligt og nuanceret formulere præcis den politik, Rådets medlemmer er enige om. Konsensus er ofte skrøbelig, og en enkelt formulering kan være et resultat af lange og hårde forhandlinger. Omvendt er NATOs dagsorden omfangsrig. Der er mange emner at vælge imellem, og dermed kan en generalsekretær i nogen grad drive et bestemt tema; en bestemt politisk dagsorden $\mathrm{i}$ NATO.

Som en sidste del af jobbets funktion har generalsekretæren adgang til medlemslandenes øverste politiske beslutningstagere. Generalsekre- tærens rolle som mødeleder gør, at han ofte konsulterer og forhandler med regeringschefer og ministre. Derigennem har han mulighed for, hvis ikke direkte at påvirke dem, så uhindret at give dem sin vinkel på et politisk emne.

Der findes altså institutionelle ressourcer og muligheder for at øve indflydelse i jobbet som generalsekretær. Generalsekretæren formulerer ikke politik, men han har indflydelse på den førte politik. Igennem sin position og sin adgang har generalsekretæren dagsordensættende magt - både internt i organisationen og i den brede offentlighed. Han kan tage ejerskab på emner og drive dem frem.

Men det er ikke generalsekretærens opgave at drive en - eller nogens - dagsorden frem for andre. Formelt set er han sekretær, og han skal være påpasselig med at overtræde de formelle grænser. Det er i første omgang en generalsekretærs personlige og politiske kapital og det daglige arbejde, der afgør hans succes. En generalsekretærs betingelser for politisk indflydelse skabes ved, at han placerer sig selv som en central, men upartisk og faciliterende, medspiller i forhold til at finde og måske endda rykke konsensus i NATO. Kun ved at placere sig selv som uundværlig i kraft af sin personlige integritet, sit konsensussøgende politiske håndværk og sit politiske netværk kan man øve indflydelse på organisationen. 
For en ny generalsekretær som Anders Fogh Rasmussen gælder, at han i kraft af sit internationale netværk og sit CV - sit ry som en god og troværdig forhandler, sit efter sigende gode forhold til sine tidligere kolleger og som afgående regeringschef - tager betydelig politisk og personlig kapital med i jobbet.

I sidste ende dømmes en generalsekretær imidlertid på sine handlinger; på hvordan han udfylder jobbet. Som sagt; en dygtig generalsekretær er en magtfuld generalsekretær. Derfor handler det for Fogh om at komme godt i gang; at vise resultater.

\section{Et bud på Foghs plan}

Hvilke emner og problemer står Fogh overfor i forhold til at komme godt i gang, og hvad vil han lægge vægt på?

På trods af NATOs krig i Afghanistan arver Fogh et NATO i bedre stand end set længe. Men netop derfor arver han også en ambitiøs dagsorden med høje forventninger. Ved jubilæumstopmødet i april 2009 genindtrådte Frankrig i NATOs militære struktur efter mere end 40 års fravær. Det udtrykker en helt ny og positiv fransk transatlantisk holdning. På den anden side af Atlanten udtrykker Obamas administration en grundlæggende tro på multilateralt samarbejde og på NATO i særdeleshed. På samme jubilæumstopmøde besluttede Alliancen at begyn- de udarbejdelsen af et nyt strategisk koncept for Alliancen. Et arbejde, der er lagt i hænderne på den nye generalsekretær.

Det nye strategiske koncept kommer til at blive Anders Foghs første udfordring og svendeprøve som generalsekretær. Udarbejdelsen af et nyt strategisk koncept er et kompliceret politisk spil, hvor store dele af NATO er til genforhandling. Samtidig er det blevet besluttet, at processen skal være åben og delvist offentlig. Fogh skal altså ikke bare styre processen i det Nordatlantiske Råd, han skal også styre en offentlig strategisk og politisk debat og sørge for, at der skabes konsensus om begge blandt alle 28 medlemslande, der kan lede til et brugbart og fremtidssikret dokument.

I forlængelse af arbejdet med det strategiske dokument - hvis det kommer sikkert i hus - tegner der sig både udfordringer og muligheder. Med den nye fransk-amerikanske forsoning i NATO er der en forventning om, at det kronisk dysfunktionelle forhold mellem EU og NATO kan komme på ret spor. Franskamerikansk mistro har indtil videre ligget i vejen for fremskridt imod et styrket sikkerhedspolitisk samarbejde mellem de to organisationer. Et EU med en vedtaget Lissabon-traktat, et godt fransk-amerikansk forhold, og et NATO med et nyt strategisk koncept gør det muligt at håbe på fremskridt.

En anden udfordring er Afghani- 


\section{KRISTIAN SØBY KRISTENSEN}

stan. På den ene side er missionen definerende for NATO i dag, og meget drejer sig naturligt om den. Men der kommer en dag i NATO efter Afghanistan. Både nu i forhold til det strategiske koncept og senere bliver det en udfordring at få defineret NATOs sikkerhedspolitiske rolle i tiden efter Afghanistan.

Et sidste område, som Fogh kommer til at bruge energi på, er organisatoriske reformer. Med ansættelsen af Michael Ulveman har Fogh allerede indikeret et fokus på en reform af NATOs politiske kommunikation, som rigtigt nok lader meget tilbage at ønske. Men i det hele taget kan NATO - både den civile og den militære del - trænge til en reform. Et succesfuldt strategisk koncept ville fungere som en væsentlig løftestang i forhold til den reformproces.

Anders Fogh Rasmussen kan blive en central aktør i forhold til alle disse centrale emner. Den politiske situation gør, at der er forventninger til NATO og til Anders Foghs evner. Men først skal han bevise sit værd som generalsekretær; at han kan håndværket. Forudsætningen for at Anders Fogh Rasmussen formår at blive general frem for sekretær i NATO, er at han lykkes med det strategiske koncept.

Kristian Søby Kristensen er forsker ved Dansk Institut for Militare Studier, hvor han er ved at lagge sidste hånd på en ph.d. om NATOs relationer uden for det transatlantiske område. 